\title{
Tissue Culture Using Mature Material for the Conservation of Oaks
}

\author{
Andrea N. Brennan ${ }^{1,5}$, Valerie C. Pence ${ }^{2}$, Matthew D. Taylor ${ }^{3}$, \\ Brian W. Trader ${ }^{3}$, and Murphy Westwood ${ }^{4}$
}

AdDITIONAL INDEX wORDs. Quercus, in vitro culture, micropropagation, ontogenetic age

\begin{abstract}
Summary. Tissue culture using mature-phase plant material is a useful tool for species conservation, but can be a challenge with oak (Quercus) species, often resulting in low growth and survival. Two different tissue culture media were compared and used to determine whether there was a survival, growth, or contamination response pattern in species representing three North American oak taxonomic sections: red oaks (section Lobatae), white oaks (section Quercus), and golden oaks (section Protobalanus). Mature phase cuttings were harvested in springtime from 12 oak species: arkansas oak (Q.arkansana), canby oak (Q. canbyi), slender oak (Q. graciliformis), nuttall oak (Q. texana), boynton sand post oak (Q. boyntonii), california scrub oak (Q.dumosa), engelmann oak (Q. engelmannii), gambel oak (Q. gambelii), canyon live oak (Q. chrysolepis), palmer oak (Q. palmeri), island oak (Q. tomentella), and huckleberry oak (Q. vacciniifolia). Excised shoot-tip explants were placed onto either Lloyd and McCown woody plant (WP) medium or Gresshoff and Doy (GD) medium. More growth responses and longer survival times were seen on explants grown on the WP medium than GD medium. Explants originating from species native to xeric habitats or those with smooth, glabrous young leaves had significantly higher contamination rates. Although no significant differences were found when grouped by taxonomic section, survival, growth, and contamination varied significantly by species. These findings contribute to the process of establishing tissue culture methods using mature oak material, particularly in relation to medium selection and sterilization protocols, which is critical to the conservation of this iconic group of species.
\end{abstract}

$\mathrm{O}$ aks [beech family (Fagaceae)] are globally iconic trees, prized for their contributions as keystone species, their landscape value, and their strong, rot-resistant wood. Despite their importance, many

We thank Longwood Gardens and the University of Delaware for supporting and funding our research. We also thank the nine gardens and arboreta supplying oak material: The Arnold Arboretum of Harvard University; Bartlett Tree Research Laboratories Arboretum; The Huntington Botanical Gardens; JC Raulston Arboretum at North Carolina State University; The Morris Arboretum of the University of Pennsylvania; The Morton Arboretum; Rancho Santa Ana Botanic Garden; The Santa Barbara Botanic Garden; and the University of California Botanical Garden at Berkeley. Many thanks also to Thomas Ilvento, Xiaoke Liu, and Jingrong Xie for their assistance with statistical analysis.

${ }^{1}$ Department of Forestry and Natural Resources, Hardwood Tree Improvement and Regeneration Center, Purdue University, 715 West State Street, West Lafayette, IN 47907

${ }^{2}$ Center for Conservation and Research of Endangered Wildlife, Cincinnati Zoo and Botanical Garden, 3400 Vine Street, Cincinnati, OH 45220

${ }^{3}$ Longwood Gardens, P.O. Box 501, Kennett Square, PA 19348

${ }^{4}$ The Morton Arboretum, 4100 Illinois Route 53, Lisle, IL 60532

${ }^{5}$ Corresponding author. E-mail: anbrenna@purdue. edu.

doi: 10.21273/HORTTECH03801-17 species of oaks are under threat globally from a range of issues, such as habitat loss, competition from invasive species, and attacks from pests and diseases (Kramer and Pence, 2012; Oldfield and Eastwood, 2007). Of the 175 oak species able to be fully evaluated for the International Union for Conservation of Nature's Red List of Oaks (Oldfield and Eastwood, 2007 ), roughly $45 \%$ were categorized as critically endangered, endangered, vulnerable, or near threatened. Conservation of this genus is challenging because oak acorns do not survive the methods used for long-term seed banking, an important plant conservation method (Bonner, 2003). One tool to support conservation efforts is tissue culture (in vitro culture or micropropagation) (Hartmann et al., 2002; Pence, 2010). Tissue culture can be used to maintain conservation germplasm collections in cultivation (ex situ) for intermediate-term storage (Guerrant et al., 2004; Pence, 2011 ), increase the number of individuals for conservation both outside and inside native habitat (in situ) (Guerrant et al., 2004; Pence, 2011), and supply shoot tips or somatic embryos for cryopreservation (Hartmann et al., 2002; Pence, 2010, 2011). Tissue culture methods are also needed for the recovery of zygotic embryo axes from cryopreservation, another potential conservation method for oaks (Xia et al., 2014).

Oak tissue culture research has predominantly focused on a handful of economically important, rather than threatened, species. These include english oak [Quercus robur (Chalupa, 1988; Vieitez et al., 1994), northern red oak [Q. rubra (Vengadesan and Pijut, 2009; Vieitez et al., 1993)], and cork oak [Q. suber (Manzanera and Pardos, 1990; Romano et al., 1992)]. Only three studies were found investigating tissue culture propagation of threatened oak species, conducted by Kramer and Pence (2012) studying maple-leaved oak (Q. acerifolia), arkansas oak, boynton sand post oak, and georgia oak (Q. georgiana); Kartsonas and Papafotiou (2007) studying dwarf trojan oak (Q. euboica); and Tamta et al. (2008) studying brown oak (Q. semecarpifolia).

In addition, there have been fewer reports on culturing oaks from mature material than from juvenile material as it tends to be more difficult to establish and grow in culture (Kartsonas and Papafotiou, 2007; Vieitez et al., 1993). Despite having better establishment in tissue culture, juvenile material is not always feasible to obtain, especially from threatened oak species. With few trees to produce them, the availability of acorns from threatened species for seedling material

\begin{tabular}{llll}
\hline $\begin{array}{l}\text { Units } \\
\begin{array}{l}\text { To convert U.S. to SI, } \\
\text { multiply by }\end{array}\end{array}$ & U.S. unit & SI unit & $\begin{array}{l}\text { To convert SI to U.S., } \\
\text { multiply by }\end{array}$ \\
\hline 29.5735 & $\mathrm{fl} \mathrm{oz}$ & $\mathrm{mL}$ & 0.0338 \\
2.54 & inch $(\mathrm{es})$ & $\mathrm{cm}$ & 0.3937 \\
25.4 & inch $(\mathrm{es})$ & $\mathrm{mm}$ & 0.0394 \\
1 & $\mathrm{ppm}$ & $\mathrm{mg} \cdot \mathrm{L}^{-1}$ & 1 \\
$\left({ }^{\circ} \mathrm{F}-32\right) \div 1.8$ & ${ }^{\circ} \mathrm{F}$ & ${ }^{\circ} \mathrm{C}$ & $\left({ }^{\circ} \mathrm{C} \times 1.8\right)+32$
\end{tabular}


can be low. This is a particular challenge because seedlings from threatened species are also needed for propagation and population reinforcement, limiting the amount available to divert to tissue culture (Guerrant et al., 2004; Kramer and Pence, 2012). Furthermore, verification of seedling parentage may be hard to determine because oak species hybridize easily (Kramer and Pence, 2012; Oldfield and Eastwood, 2007). Depending on the circumstances, the basal branches may or may not be present on individual plants. Acquiring stump sprouts is not practical when there are only a limited number of individuals available because the primary method of production of these sprouts is to cut a tree down to the stump (Wendling et al., 2014). Wounding or removal of root material for induction of adventitious shoots could injure and harm the plant by creating entry for pests and pathogens, and depleting the tree's carbohydrate storage (Kramer and Kozlowski, 2012). Therefore, determining, a reliable method of tissue culture involving mature-phase material would be useful in overcoming the challenges of obtaining juvenilephase plant material from threatened species.

With $\approx 500$ oak species in the world (Oldfield and Eastwood, 2007), it would be valuable to predict oak tissue culture responses by taxonomic group and establish protocols that could be generalized across related species. The first objective was to determine which of the two commonly used media in the tissue culture of beech family species, Lloyd and McCown WP medium (Lloyd and McCown, 1980) or GD medium (Gresshoff and Doy, 1972), was more effective in the establishment, growth, and multiplication of material from mature phase material from a range of oak species. The second objective of this study was to determine whether there was a pattern in tissue culture responses (growth, survival, and contamination) by species or section. The third objective was to determine whether there was a tissue culture response pattern by the moisture level of natural habitat (mesic or xeric) or young leaf texture (rugose and hairy or smooth and glabrous).

\section{Materials and methods}

Plant material. Twelve oak species native to the southern United States and adjacent Mexico were used, including both threatened and nonthreatened species representing three different oak sections of North America (Nixon, 2006) (Table 1). Living collections in nine U.S. public gardens and arboreta containing these species were identified by working with the program director of Botanic Gardens Conservation International U.S. and through the PlantSearch Database (Botanic Gardens Conservation International, 2014). Depending on availability, material was obtained from one to three different institutions and from two to five different individual specimens for each species. Cuttings with 1-year-old growth from mature plants were collected in early spring during budbreak, and expressmailed to Longwood Gardens (Kennett Square, PA). The protocol for collecting and sending cuttings was modified from methods used by Kramer and Pence (2012), and excludes the fifth step, which involved the additional collection of old growth (juvenile) material.

Cuttings were collected between February and May, depending on the timing of budbreak at each source locality. On arrival, the bases of all cuttings were recut and immediately placed into distilled water. Cuttings with emerging leaves were allowed to sit in distilled water for at least $15 \mathrm{~min}$ to regain turgidity and then young shoots with at least one fully open leaf blade (target stage) were collected to be used as explants (Fig. 1). Cuttings without emerging leaves were placed in greenhouse conditions, with water changed twice weekly, until leaf emergence, at which point shoot tips at the target stage were removed.

Table 1. Oak section and species, moisture level of natural habitat, young leaf texture [rugose and hairy (RH), smooth and glabrous (SG)], number of source locations, number of source (mother) plants, number of explants, and mean survival time of explants grown in tissue culture. Species mean survival times, with standard error, are compared using Tukey-Kramer honestly significant difference (HSD) test.

\begin{tabular}{|c|c|c|c|c|c|c|c|c|}
\hline Section/species name & $\begin{array}{c}\text { Natural } \\
\text { habitat }\end{array}$ & $\begin{array}{c}\text { Young leaf } \\
\text { texture }\end{array}$ & $\begin{array}{c}\text { Source } \\
\text { locations (no.) }\end{array}$ & $\begin{array}{c}\text { Source } \\
\text { trees (no.) }\end{array}$ & $\begin{array}{c}\text { Explants } \\
\text { (no.) }\end{array}$ & $\begin{array}{c}\text { Mean survival } \\
\text { time }(\mathrm{d})\end{array}$ & $\begin{array}{c}\text { HSD test letter } \\
\text { group }^{z}\end{array}$ & SE \\
\hline Red oaks & - & - & 5 & 14 & 192 & 33.4 & - & - \\
\hline Canby oak & Xeric & SG & 3 & 4 & 50 & 48.7 & $a b c$ & 1.6 \\
\hline Slender oak & Mesic & SG & 1 & 3 & 52 & 40.8 & $a b$ & 1.2 \\
\hline Nuttall oak & Mesic & SG & 2 & 2 & 36 & 20.7 & $\mathrm{bc}$ & 1.2 \\
\hline California scrub oak & Xeric & SG & 1 & 2 & 18 & 84.3 & a & 1.4 \\
\hline Engelmann oak & Xeric & $\mathrm{RH}$ & 2 & 4 & 44 & 25.6 & bc & 1.2 \\
\hline Gambel oak & Xeric & $\mathrm{RH}$ & 2 & 4 & 48 & 23.9 & $a b c$ & 1.4 \\
\hline Golden oaks & - & - & 4 & 11 & 87 & 25.0 & - & - \\
\hline Canyon live oak & Xeric & $\mathrm{RH}$ & 2 & 2 & 12 & 14.0 & $\mathrm{bc}$ & 1.4 \\
\hline
\end{tabular}

${ }^{\mathrm{z}}$ Species not connected by the same letter are significantly different.

${ }^{y}$ Overall species mean survival time, not a total. 
Unless otherwise stated, all chemicals and supplies were manufactured by PhytoTech Laboratories in Overland Park, KS. Excised shoots were surface sterilized with a $1: 10$ dilution of commercial bleach (Clorox, Oakland, CA) with $0.05 \%$ surfactant (Tween 20 ) for $10 \mathrm{~min}$ with stirring. Explants were then

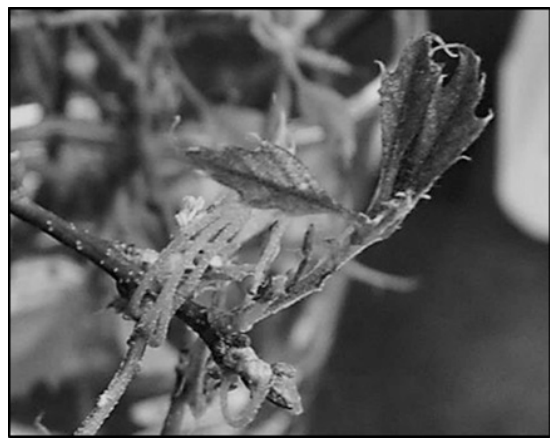

Fig. 1. Image of a young shoot tip of canby oak at target explant harvest stage for tissue culture. rinsed with sterile, distilled water with agitation for at least $1 \mathrm{~min}$. If the leaf blades of the young shoots were greater than $1 \mathrm{~cm}$ in length, they were cut to $1 \mathrm{~cm}$ after the water rinse to prevent excess transpiration and water loss from the explant. Immediately before culturing, explant bases were recut to remove the exposed tissue damaged by bleach during sterilization.

Growing CONDITIONs. Oak explants were grown on two different medium formulations: 1) WP medium basal salts (Lloyd and McCown, 1980) with Murashige and Skoog vitamins (Murashige and Skoog, 1962) or 2) GD medium basal salts and vitamins (Gresshoff and Doy, 1972). A comparison of select nutrients in WP and GD media based on the product labels is shown in Fig. 2. Both media formulations were amended with $3 \%$ sucrose, $0.6 \%$ agar, $0.89-\mu \mathrm{M}$ 6-benzylaminopurine, and $100-\mathrm{mg} \cdot \mathrm{L}^{-1}$ of benomyl fungicide

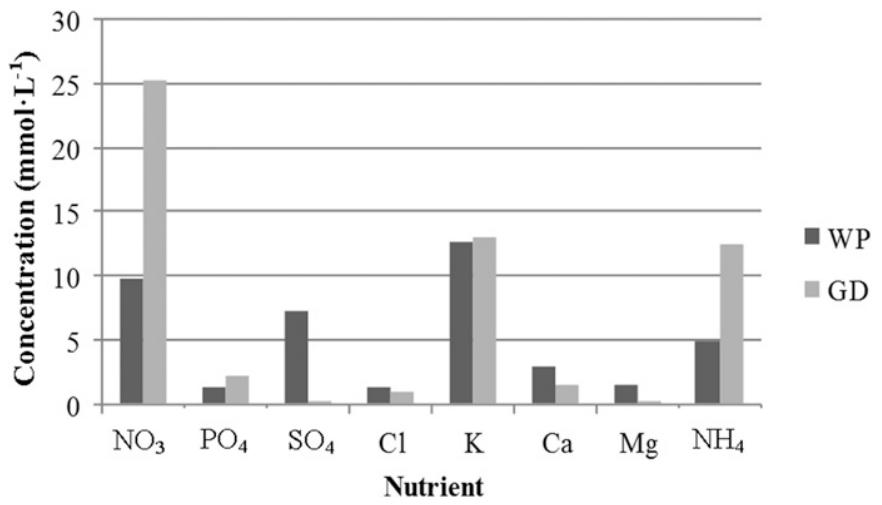

Fig. 2. Nutrient comparison of Lloyd and McCown woody plant medium (Lloyd and McCown, 1980) and Gressoff and Doy medium (Gresshoff and Doy, 1972). Data in figure were taken from the medium product labels (PhytoTech Laboratories); $\mathrm{NO}_{3}=$ nitrate; $\mathrm{PO}_{4}=$ phosphate; $\mathrm{SO}_{4}=$ sulfate; $\mathrm{Cl}=$ chlorine; $\mathrm{K}=$ potassium; $\mathrm{Ca}=$ calcium; $\mathrm{Mg}=$ magnesium; $\mathrm{NH}_{4}=$ ammonia.

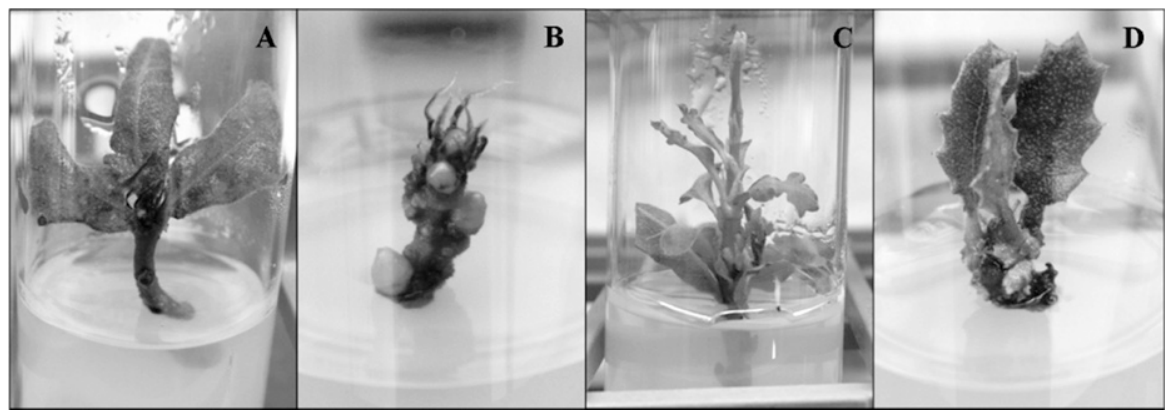

Fig. 3. Images of oak explant growth responses in tissue culture: (A) expansion of preexisting leaves in boynton sand post oak, $(B)$ bud enlargement in engelmann oak, (C) shoot production in gambel oak, and (D) callus production in california scrub oak.

(Benlate; Sigma-Aldrich, St. Louis, MO). The fungicide was added to the media because fungal contamination can be a significant challenge when growing oak species in tissue culture (Kartsonas and Papafotiou, 2007; Kramer and Pence, 2012; Romano et al., 1992). During the first 3 weeks, explants were transferred to fresh media two to three times per week based on visible exudation of phenolic compounds. Thereafter, explants were then transferred every 1-2 weeks.

Depending on the number of viable buds and size of each cutting, 12-54 explants were obtained from each of the 12 oak species, for a total of 419 explants split between the two media (Table 1). Because of the low availability of some species (plant deaths during a harsh winter or cutting death in transit), anticipated sample numbers were not obtained for some of the species. Each explant was grown separately on $\approx 15 \mathrm{~mL}$ of medium in a $25 \times 150-\mathrm{mm}$ culture tube with a translucent polypropylene closure secured with sealing film (parafilm; Bemis Company, Neenah, WI). Cultures were grown at 22.5 to $25.5{ }^{\circ} \mathrm{C}$ and under cool white fluorescent light at $\approx 20-25 \mu \mathrm{mol} \cdot \mathrm{m}^{-2} \cdot \mathrm{s}^{-1}$ for $24 \mathrm{~h}$ per day.

Data ANAlysis. Data on growth responses, contamination, and survival times were collected each time the explants were transferred onto fresh media. The term "growth responses" is used collectively here to refer to the expansion of preexisting leaves, bud enlargement, shoot production, and callus production (Fig. 3 ), taken as presence or absence data. Although each type was tracked separately, there were not enough responses across replicates to conduct a statistical analysis of each growth response (i.e., expansion of leaves, bud enlargement, shoot production, and callus production) by species. Ultimately, the growth response types were combined together for the presence or absence of any type of response to conduct a statistical analysis on growth. Death was defined as complete browning of the explant. Using JMP statistical software (SAS Institute, Cary, NC), growth and contamination were evaluated using contingency analysis and Pearson's chi-squared test. A subsequent test using logistic regression, 
and a contrast of the log odds was used to determine which species had significantly different contamination rates. Explants affected by contamiand survival time analyses. Survival times were evaluated using one-way analysis of variance (ANOVA). The survival time distribution was skewed right and not normally distributed, which affects the reliability of the ANOVA. To normalize the distribution, the natural $\log$ of each of the survival times was used for this analysis. An alpha level of 0.05 was considered significant for all statistical analyses. The primary variables investigated were species, section, medium type, moisture level of natural habitat, and young leaf texture.

Contamination. The overall contamination rate was $48 \%$, but varied significantly by species $(P<0.0001)$. Of the 12 oak species, explants of canby oak, gambel oak, slender oak, and huckleberry oak showed significantly higher contamination $(P<0.0001)$, with rates of $92 \%, 85 \%, 64 \%$, and $60 \%$, respectively (Fig. 4). No significant differences were found analyzing contamination by taxonomic section $(P=0.21)$ or medium $(P=0.16)$. When grouped by natural habitat, explants from xeric habitats had a significantly higher contamination rate $(57 \%)$ than those from mesic habitats nation were excluded from the growth

\section{Results}

(36\%) $(P<0.0001)$. When grouped by young leaf texture, explants with smooth, glabrous leaves had a significantly higher contamination rate $(57 \%)$ than those with rugose, hairy leaves $(40 \%)(P=0.0006)$.

Survival TIME. Mortality was high across all species when analyzed by oak section and medium (Fig. 5 ), with an overall mean survival time of just over $30 \mathrm{~d}$ (excluding contaminated explants). Survival time varied significantly by oak species $(P<0.0001)$. Explants of california scrub oak and huckleberry oak had the longest mean survival times, whereas those of canyon live oak and palmer oak had the shortest (Table 1). The differences in survival times among the species were concealed when grouped by section, and there was no significant difference found in mean survival time between the three sections $[P=$ 0.25 (Fig. 5A)]. Medium was shown to be a significant variable for survival time, with explants growing on the WP medium living over $13 \mathrm{~d}$ longer on average than those on the GD medium $[P=0.0013$ (Fig. 5B) $]$. No significant differences were found in mean survival time when grouped by moisture level of natural habitat $(P=$ $0.44)$ or leaf texture $(P=0.91)$.

GrowTH RESPONSES. Growth responses were low among all species, with 40 of 216 noncontaminated

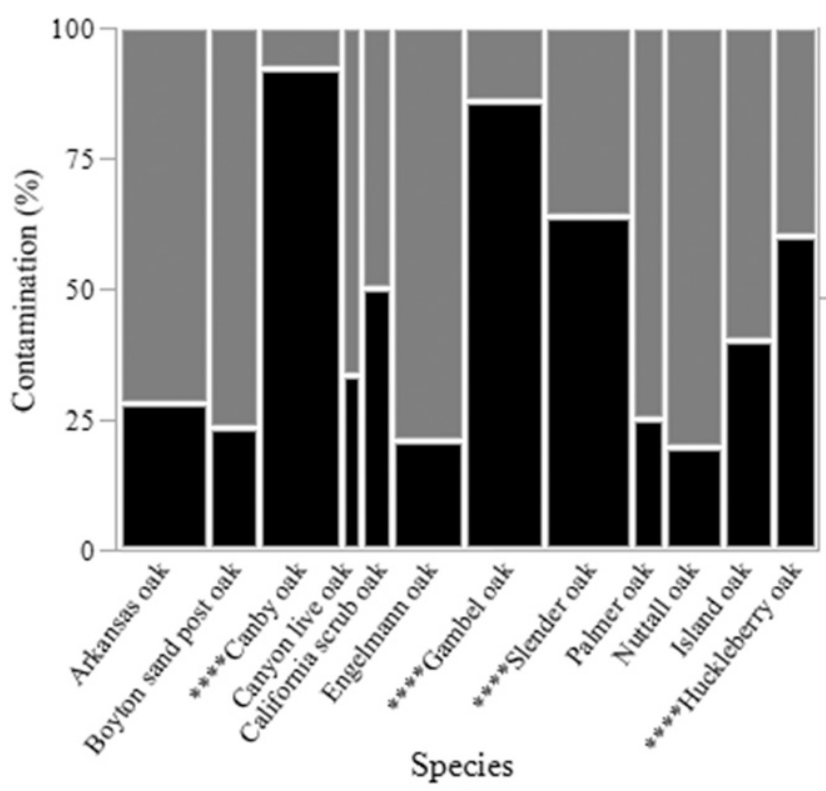

Fig. 4. Percentage of oak explants grown in tissue culture affected by contamination by species. Species marked with **** have significantly higher contamination rates than the other species at $P<0.0001$ using logistic regression and a contrast of the log odds. Column width correlates with sample size $(n)$. explants exhibiting some growth. Growth was seen in nine of the species: arkansas oak, slender oak, nuttall oak, boynton sand post oak, california scrub oak, engelmann oak, gambell oak, island oak, and huckleberry oak, whereas no growth was observed in canby oak, canyon live oak, and palmer oak. Expansion of preexisting leaves was seen in 20 explants across five species: arkansas oak, boynton sand post oak, engelmann oak, gambel oak, and island oak. Bud enlargement was observed in 12 explants from five species: arkansas oak, slender oak, engelmann oak, gambel oak, and huckleberry oak. Although some enlarged buds eventually broke and developed into new shoots, most explants exhibiting this response turned brown and declined before the buds could develop further. Callus was seen in 10 explants from five species: slender oak, nuttall oak, boynton sand post oak, california scrub oak, and engelmann oak. When callus growth occurred, it grew from many different tissue types (leaves, stems, petioles, meristems, etc.). The exception to this was nuttall oak, where callus growth was only noted on the bases of petioles of abscising leaves. There were five observations of the primary target growth response, production of new shoots, in two species: arkansas oak and gambel oak. Growth of new shoots was noted on average around day 30 for arkansas oak explants and on average around day 60 for gambel oak explants. Only one explant (gambel oak) produced multiple shoots. Growth response was found to be independent of section $(P=0.35)$, natural habitat $(P=0.13)$, and leaf texture $(P=0.08)$. However, a relationship was found between growth response and medium, with significantly more explants having growth responses on the WP medium than those on GD $(P=0.03)$.

\section{Discussion and conclusion}

Contamination rates were significantly higher in canby oak, gambel oak, slender oak, and huckleberry oak compared with the other eight species in the experiment. Explant material for these four species came from multiple tree specimens. In addition, only cuttings from slender oak were sourced from one location, whereas the other three species were represented by material obtained from at 


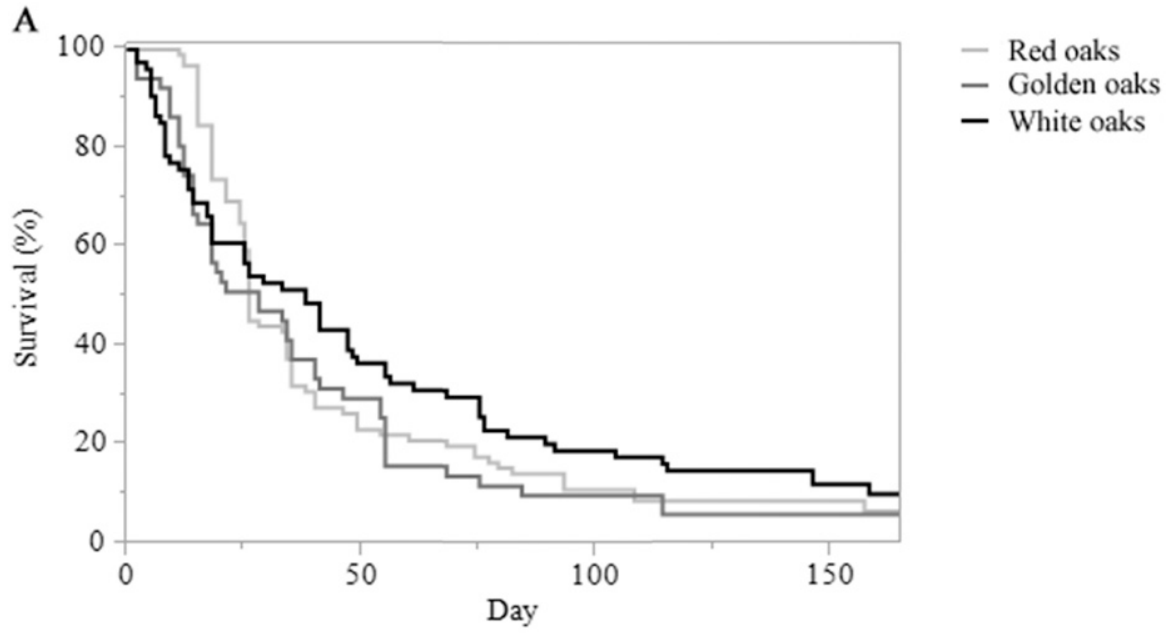

B

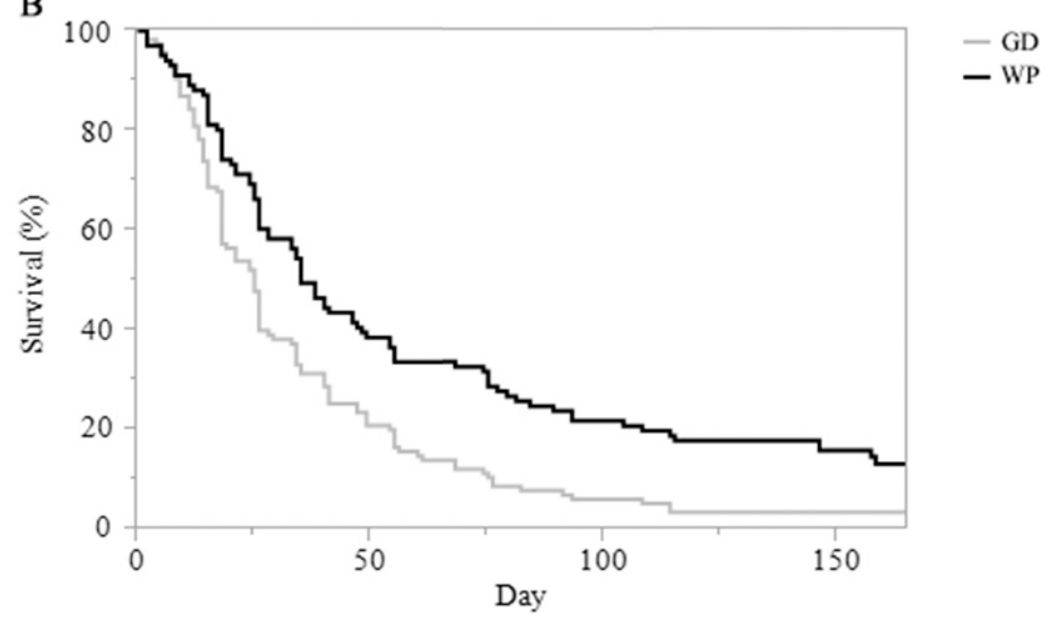

Fig. 5. Percent of oak explants surviving over time in tissue culture by (A) section and (B) medium: Lloyd and McCown woody plant (WP) medium (Lloyd and McCown, 1981) and Gressoff and Doy (GD) medium (Gresshoff and Doy, 1972).

least two different sources. Thus, contamination linked to specific sources is an unlikely cause of the higher rate of contamination seen in these species. This variability in contamination levels between oak species was also reported by Kramer and Pence (2012). Moisture level of natural habitat and young leaf texture also appeared to play a role in contamination rates, with explants from xeric habitats or with smooth, glabrous young leaves having significantly higher contamination rates. It is possible that the specific endophyte species associated with these factors could be responsible for the contrasting contamination rates. Ragazzi et al. (2003) analyzed the leaves and twigs of three oak species [turkey oak ( $Q$. cerris), downy oak (Q. pubescens), and english oak] and found significant differences in endophytic mycobiota species composition between them.
Survival times were significantly longer for explants growing on the WP medium formulation than the GD formulation. No published research formally tracking and comparing tissue culture survival times of oak species was found for comparison. However, no significant differences were observed by Meier and Reuther (1994) in survival times between european beech (Fagus sylvatica) explants growing on WP vs. those on GD media.

With fewer than $19 \%$ of noncontaminated explants exhibiting a growth response, this study supports previous findings that the tissue culture of mature-phase oak material is difficult (Kartsonas and Papafotiou, 2007; Kramer and Pence, 2012; Vieitez et al., 1993). There were significantly more growth responses for oak explants on the WP medium than the GD medium, which was also seen by Kramer and Pence (2012) in maple-leaved oak, arkansas oak, boytnon's sand post oak, and georgia oak, but is contrary to the results of Romano et al. (1992) in cork oak. The levels of growth responses, especially new shoot production, were low overall, and similar to levels reported by Kramer and Pence (2012) and Vieitez et al. (1993) when using mature phase oak shoot tips. No significant growth response or survival time patterns were observed when grouping by natural habitat or leaf texture.

Contamination levels, survival time, and growth responses varied by oak species, but no significant patterns emerged when grouped by taxonomic section. Thus, it appears that differences between oak species may be great enough that their responses in tissue culture are unlikely to be predictable by section. Based on the literature, this is the first attempt to compare tissue culture responses of oak species by section.

As our results indicate that WP could be a better medium for growing mature phase oak explants in tissue culture than GD, future research should explore the effects of specific nutrient concentrations in media. It would be of particular interest to determine if the lower nitrogen and higher sulfur content of the WP medium (Fig. 2) are important factors. Species from xeric habitats and those with smooth, glabrous new leaves showed higher levels of contamination, and future work with such species might include more rigorous sterilization protocols and perhaps increased levels of fungicide or the addition of antibiotics into the medium (Gamborg and Phillips, 2013). Collecting shoots resulting from forced dormant twigs or from scion grafts of selected species on to an appropriate rootstock could allow for fresher shoot material, while also eliminating some of the other challenges associated with long distance transport of harvested shoot material (Yang and Read, 1992). Although no significant growth or survival patterns emerged by taxonomic section, moisture level of natural habitat, or young leaf texture, further studies should consider testing species response patterns in other ways, such as geographic range, to look for correlations that might help in predicting responses in tissue 
culture. Such information would increase the efficiency and effectiveness of the methods available for conserving threatened oak species.

In conclusion, the current study indicates that WP may be a more effective medium for oaks in tissue culture, particularly when dealing with an oak species new to culture. In addition, our research shows that native habitat and the texture of new leaves could affect how strong sterilization and other contamination prevention protocols need to be. Our research also reinforces previous findings that growth responses in tissue culture can vary widely between even closely related species (Wada et al., 2013). These findings contribute to the process of establishing much needed tissue culture methods for oaks using mature material, which is critical to the future conservation of this iconic group of species (Kramer and Pence, 2012; Pence, 2010).

\section{Literature cited}

Bonner, F. 2003. Care and collection of acorns: A practical guide for seed collectors and nursery managers. U.S. Dept. Agr. For. Serv. Natl. Seed Lab., Dry Branch, GA.

Botanic Gardens Conservation International. 2014. PlantSearch database. 20 Apr. 2015. <http://www.bgci.org/ plant_search.php>.

Chalupa, V. 1988. Large scale micropropagation of Quercus robur L. using adenine-type cytokinins and thidiazuron to stimulate shoot proliferation. Biol. Plant. 30:414-421.

Gamborg, O.L. and G. Phillips. 2013. Plant cell, tissue and organ culture: Fundamental methods. Springer, Berlin, Germany.

Gresshoff, P.M. and C.H. Doy. 1972. Development and differentiation of haploid Lycopersicon esculentum (tomato). Planta 107:161-170.

Guerrant, E.O., K. Havens, and M. Maunder. 2004. Ex situ plant conservation: Supporting species survival in the wild. Vol. 3 . Island Press, Washington, DC.
Hartmann, H.T., D.E. Kester, F.T. Davies, Jr., and R.L. Geneve. 2002. Plant propagation - Principles and practices. 7th ed. Prentice Hall, Upper Saddle River, NJ.

Kartsonas, E. and M. Papafotiou. 2007. Mother plant age and seasonal influence on in vitro propagation of Quercus euboica Pap., an endemic, rare and endangered oak species of Greece. Plant Cell Tissue Organ Cult. 90:111-116.

Kramer, A.T. and V. Pence. 2012. The challenges of ex-situ conservation for threatened oaks. Intl. Oaks 23:91-108.

Kramer, P. and T.T. Kozlowski. 2012. Physiology of woody plants. Academic Press, New York, NY.

Lloyd, G. and B. McCown. 1980 Commercially-feasible micropropagation of mountain laurel, Kalmia latifolia, by use of shoot-tip culture. Comb. Proc. Intl. Plant Propagators' Soc. 30:421-427.

Manzanera, J.A. and J.A. Pardos. 1990. Micropropagation of juvenile and adult Quercus suber L. Plant Cell Tissue Organ Cult. 21:1-8.

Meier, K. and G. Reuther. 1994. Factors controlling micropropagation of mature Fagus sylvatica. Plant Cell Tissue Organ Cult. 39:231-238.

Murashige, T. and F. Skoog. 1962. A revised medium for rapid growth and bio assays with tobacco tissue cultures. Physiol. Plant. 15:473-497.

Nixon, K. 2006. Global and neotropical distribution and diversity of oak (genus Quercus) and oak forests, p. 3-13. In: M.M. Caldwell, G. Heldmaier, R.B. Jackson, O.L. Lange, H.A. Mooney, E.-D. Schulze, and U. Sommer (eds.). Ecology and conservation of neotropical montane oak forests. Springer, Berlin, Germany.

Oldfield, S. and A. Eastwood. 2007. The red list of oaks. Fauna Flora Intl., Cambridge, UK.

Pence, V.C. 2010. The possibilities and challenges of in vitro methods for plant conservation. Kew Bull. 65:539-547.

Pence, V.C. 2011. Evaluating the costs for the in vitro propagation and preservation of endangered plants. In Vitro Cell. Dev. Biol. Plant 47:176-187.
Ragazzi, A., S. Moricca, P. Capretti, I. Dellavalle, and E. Turco. 2003. Differences in composition of endophytic mycobiota in twigs and leaves of healthy and declining Quercus species in Italy. For. Pathol. 33:31-38.

Romano, A., M. Martins-Loucao, and C. Noronha. 1992. Influence of growth regulators on shoot proliferation in Quercus suber L. Ann. Bot. (Lond.) 70:531-536.

Tamta, S., L.M.S. Palni, V.K. Purohit, and S.K. Nandi. 2008. In vitro propagation of brown oak (Quercus semecarpifolia $\mathrm{Sm}$.) from seedling explants. In Vitro Cell. Dev. Biol. Plant 44:136-141.

Vengadesan, G. and P.M. Pijut. 2009. In vitro propagation of northern red oak (Quercus rubra L.). In Vitro Cell. Dev. Biol. Plant 45:474-482.

Vieitez, A.M., A. Ballester, J. AmoMarco, and M.C. Sanchez. 1994. Forced flushing of branch segments as a method for obtaining reactive explants of mature Quercus robur trees for micropropagation. Plant Cell Tissue Organ Cult. 37:287295.

Vieitez, A.M., F. Pintos, M.C. San-Jose, and A. Ballester. 1993. In vitro shoot proliferation determined by explant orientation of juvenile and mature Quercus rubra L. Tree Physiol. 12:107-117.

Wada, S., R.P. Niedez, J. DeNoma, and B.M. Reed. 2013. Mesos components $\left(\mathrm{CaCl}_{2}, \mathrm{MgSO}_{4}, \mathrm{KH}_{2} \mathrm{PO}_{4}\right)$ are critical for improving pear micropropagation. In Vitro Cell. Dev. Biol. Plant 49356-365.

Wendling, I., S.J. Trueman, and A. Xavier. 2014. Maturation and related aspects in clonal forestry - Part II: Reinvigoration, rejuvenation and juvenility maintenance. New For. 45:473-486.

Xia, K., L.M. Hill, D.Z. Li, and C. Walters. 2014. Factors affecting stress tolerance in recalcitrant embryonic axes from seeds of four Quercus (Fagaceae) species native to the USA or China. Ann. Bot. 114:1747-1759.

Yang, G. and P.E. Read. 1992. Pre-forcing treatments influence bud break and shoot elongation in forced woody species. J. Environ. Hort. 10:101-103. 